Salivary gland tumours are a group of lesions whose heterogeneity of biological and pathological features is widely reflected in the molecular aspect. This is demonstrated by an increasing number of studies in the field of genetics of these tumours.

The aim of this study was to collect the most significant scientific reports on the cytogenetic and molecular data concerning these tumours, which might facilitate the identification of potential biomarkers and therapeutic targets. The analysis covered 71 papers included in the PubMed database. We focused on the most common tumours, such as pleomorphic adenoma, Warthin tumour, mucoepidermoid carcinoma, and others. The aim of this study is to present current knowledge about widely explored genotypic alterations (such as PLAG1 gene in pleomorphic adenoma or MECT1 gene in mucoepidermoid carcinoma), and also about rare markers, like Mena or SOX10 protein, which might also be associated with tumourigenesis and carcinogenesis of these tumours.

Key words: salivary gland tumours, pleomorphic adenoma, carcinoma ex pleomorphic adenoma, molecular, genes.

Contemp Oncol (Pozn) 2016; 20 (4): 281-286 DOI: $10.5114 /$ w0.2016.61847

\section{Particular aspects in the cytogenetics and molecular biology of salivary gland tumours - current review of reports}

\author{
Aleksandra J. Ochal-Choińska, Ewa Osuch-Wójcikiewicz
}

Department and Chair of Otolaryngology, Medical University of Warsaw, Warsaw, Poland

\section{Introduction}

In 2005 the World Health Organization (WHO) published a histological classification which distinguished 10 types of benign and 24 types of malignant salivary gland tumours. Haemangiomas and tumours of the lymphoid tissue have been included in another group. All of these lesions are relatively rare, and constitute only 3-4\% of head and neck tumours. $80 \%$ of them are located within the parotid gland. It was documented that there is an epidemiological relationship showing that the ratio of benign to malignant tumours is inversely proportional to the size of the gland [1-4].

Malignant tumours originating from salivary glands represent only $0.5 \%$ of all malignancies. Approx. 15-30\% of lesions that arise from the parotid gland are malignant, as well as $40-60 \%$ of those affecting the submandibular gland, and $40-90 \%$ of minor gland lesions [1-3, 5].

According to the TNM classification (2010) of the American Joint Committee on Cancer, the major salivary gland tumours are classified into 4 stages and 6 prognostic groups (I-III, IVa-IVc) with the criteria referring to the size, extraparenchymal extension, lymph node, facial nerve involvement (in parotid tumours) and the presence of metastases. Tumours of the minor salivary glands are staged according to the anatomic site of origin. The current staging system does not take into account any molecular markers. It may be due to the fact that there is no evidence concerning specific markers that have a sufficient impact on treatment decisions [6].

Due to the lack of account in the National Register of Cancer, benign salivary gland tumours are not so thoroughly documented. On the basis of scientific reports of leading centres, it was estimated that they account for around $70 \%$ of all salivary gland tumours. Most of them are located in the superficial lobe of the parotid gland, constituting up to $80 \%$ of malignancies. This group is dominated by pleomorphic adenoma (PA) and Warthin tumour (WT) [2, 7]. However, the most common malignant tumours that have been given more attention in the present study are: adenocarcinoma, acinic cell carcinoma, mucoepidermoid carcinoma (MEC), and adenoid cystic carcinoma (ACC). Additionally, due to the enigmatic malignant transformation of the popular PA, the molecular studies of rare carcinoma ex pleomorphic adenoma (CA ex PA) were also taken into account $[2,8]$.

Salivary gland tumours present an extremely wide range of morphological diversity. The macroscopic differences are rather indistinct, but microscopically the hybrid structures or focal malignancies are not uncommon, which hinders the histopathological interpretation. A similar, or wider range of characteristic properties is also observed at the molecular level. The oncogenesis of salivary gland tumours is characterised by the progression of changes at the cellular, genetic and epigenetic level. Most of them are specific for particular tumours and are presented below. 


\section{General reports}

A wide range of signal transduction receptors and their pathways, such as tyrosine kinase c-kit (CD117), epidermal growth factor receptor (EGFR), NF- $\mathrm{B} B$ - transcription factor, Ras proteins, Wnt/ $\beta$-catenins, and ErbB/HER were tested and described with reference to salivary gland tumours. Specific exceptions concerning these processes are listed below in the detailed characteristics of particular cancer lesions [9-11].

P53 plays an uncertain role in salivary gland tumours. Despite numerous reports, it remains unclear because of frequent contradictory results. We managed to determine that p53 expression is higher in malignant lesions than in the benign ones, which was clearly observed in ACC and MEC $[12,13]$.

Recent studies have also shown several rare markers in salivary gland tumours.

The expression of Mena (actin regulatory protein, a member of Ena/VASP family, which is involved in cell motility and adhesion) was negative in normal salivary gland tissue and benign neoplasms. However, it was up-regulated in carcinomas. This finding suggests that the reorganisation of the cytoskeleton is activated during malignant transformation, and it may facilitate metastasis [14, 15].

Wilms tumour protein 1 (WT1) may be another potential marker. Its high expression is commonly associated with benign non-oncocytic salivary tumours, whereas malignant tumours show a decreased expression of this protein, which may be useful in histological differential diagnosis [16].

A recent study showed that most adenoid cystic carcinomas, epithelial-myoepithelial carcinomas, acinic cell carcinomas, and pleomorphic adenomas of the salivary glands were positive for SOX10 (SRY-related HMG-box 10) protein [17]. According to that study, mucoepidermoid carcinomas, Warthin tumours, and salivary duct carcinomas do not express SOX10. Another study showed that these tumours also lacked nestin - an intermediate filament first identified in neural progenitor cells. This suggests that SOX10 and nestin expression may be useful as novel markers for diagnosing and understanding the histogenesis of salivary gland tumours [18].

In another study concerning palatal salivary glands in the elderly, the low expression of factors capable of preserving cellular homeostasis, like maspin and AQP5 (aquaporin 5), and a high expression of factors that are related to cell survival, like HSPs (heat shock proteins), may point to their high vulnerability to selective phenotypic changes [19].

According to new data concerning associations between HPV and infection-related epidermal growth factor receptor (EGFR), cyclin-dependent kinase inhibitor 2A (CDKN2A/p16), and tumour protein p53 (TP53), it seems that salivary gland tumours are not associated with HPV infections, contrary to oral squamous cell carcinomas [20].

\section{Benign tumours}

\section{Pleomorphic adenoma}

\section{Cytogenetic and molecular aspects}

Based on the cytogenetic analysis, patients with pleomorphic adenoma were divided into four groups, depend- ing on the karyotype of the tumour: patients with normal karyotype (about 30\%), with rearrangements in 8 q12 (39\%), rearrangements in 12q13-15, and patients with other non-recurrent chromosomal aberrations (23\%). It was demonstrated that only $30 \%$ of adenomas have a normal karyotype. The remaining $70 \%$ have at least one alteration in the genotype, the most common of which are shown below $[21,22]$.

In some cases, adenoma multiforme is associated with translocations within the 8q12, 3p21, and 12q13-15 regions. The most common one is a mutual translocation $\mathrm{t}(3,8)(\mathrm{p} 21 ; \mathrm{q} 12)$, which is associated with aberrant gene expression - PLAG1 (pleomorphic adenoma gene 1). The $t(3,8)$ translocation results in the conversion of $\beta$-cateninCTNNB1 promoter gene, which is constitutively expressed in normal cells. As a result of this rearrangement, PLAG1 gene is overexpressed and the expression of CTNNB1 gene is reduced [21, 23-26]. PLAG1 gene encodes a zinc finger protein PLAG1. The gene belongs to proto-oncogenes, whose mutation (that was mentioned above) contributes to malignant transformation, both in case of adenoma multiforme and its malignant form - CA ex PA [24-27]. Increased activity of PLAG1 is often accompanied with activation of the Ras oncogene, and in contrast to CA ex PA there is no activation of proto-oncogene c-erbB2 [28, 29]. It was shown that changes in the $8 q 12$ region are characteristic for younger patients with adenoma multiforme. The histopathological analysis led to the conclusion that the stromal component of these tumours was reduced in comparison with the normal karyotype [21]. It was also reported that the trisomy of chromosome 8 may play an important role in the aetiology of adenoma multiforme, which can imply that the crucial genes for this tumour may be associated with this chromosome [21, 23-26].

Other common karyotype changes that also apply to the long arm of chromosome 12 are: $t(9,12)(p 24 ; q 14-15)$ and ins $(9,12)$ (p24;q12q15). Rearrangements within 12q1415 are associated with the deregulation of the HMGA2 gene, encoding hmga2 (protein controlling the transcription process by changing the conformation of the DNA). According to breast cancer studies, the expression of this factor is controlled by the microRNA molecule - let-37, and the overexpression of this factor confers multipotency on cells [30-32]. As well as CTNNB1-PLAG1 gene fusion, studies have shown the presence of two other fusions concerning the PLAG1 gene: SII-PLAG1 and LIFTR-PLAG1; and another two, related to the HMGA2 gene: NF1B-HMGA2 and FHIT-HMGA2. Their role in carcinogenesis requires further research. Nevertheless, all five turn out to be very specific for PA, which provides a solid base to be used as markers for these tumours [32-34].

Recent reports indicated new locations of chromosomal aberrations, which characterise PA within the following regions: 8p23, 10q25, 9p, and 11q24. However, their importance concerning particular gene expression profiles requires further research [35].

In contrast to CA ex PA, neither the mutation nor overexpression of the TP53 gene has been demonstrated in PAs [12, 36]. However, a decreased expression of human $\beta$-defensin 1 (hBD-1) was found in these tumours, which 
may confirm its role as a tumorigenesis suppressor [37]. Moreover, further studies are needed to clarify the possible role of the SV40 virus (Simian Virus 40) in carcinogenesis because the integrated DNA of SV40 was found in the genome of PA, further demonstrating the expression of one of the antigens characteristic for this virus [38].

\section{Molecular features of prognostic and predictive value}

When assessing the gene expression profile of these tumours it was demonstrated that only 16 of their genes were different from the profile of single-cell carcinoma of salivary glands, and as many as 133-447 genes differed when compared with healthy tissue. This may explain the tendency for the malignant transformation of these tumours [39, 40].

The expression of microRNA and its regulation and biosynthesis pathway proteins like Dicer, Drosha, DGCR8, and p68 were increased in this type of tumour. Also, an overexpression of the oncogene PLAG1 and WNT, MAPK, and JAK-STAT genes responsible for tumourigenesis in many other tumours may suggest the impact of miRNAs on the regulation of these oncogenes [41].

\section{Warthin tumour (adenolymphoma, cystadenolymphoma)}

Three groups reflecting the changes in the karyotype of WT were distinguished during cytogenetic analyses. The first and largest group includes tumours with a normal karyotype. The second one presents numerical changes, which were often described as the loss of the $Y$ chromosome as well as monosomy or trisomy of chromosome 5 . The third group consists of tumours presenting all structural aberrations with one or two reciprocal translocations. A study of 13 cases showed no significant changes in the karyotype of these tumours, but some reports described isolated cases of translocation $\mathrm{t}(11 ; 19)(q 21, \mathrm{p} 13)$, which is typical for MEC [42, 43].

There were reports of mitochondrial DNA damage that could lead to ultrastructural changes in mitochondria and, microscopically, to oncocytic changes [44]. A study on the $X$ chromosome-associated gene of the androgen receptor showed a monoclonal cell origin of WT, which would defy its malignant nature [45]. It seems to confirm the earlier morphology-related theory of WT histogenesis, which indicated the combination of the induced inflammatory changes with accompanying oncocytic ones [46].

\section{Malignant tumours}

\section{Mucoepidermoid carcinoma}

\section{Cytogenetic and molecular aspects}

Reports on the cytogenetics and molecular biology of this tumour are rather scarce, and they apply to a small number of cases. In many cases the translocation t(11:19) (q21;p13) was described as the single genomic alteration accompanying other numerical and structural aberrations of chromosomes. Such an aberration was found in several types of acute leukaemia $[47,48]$. A careful analysis of this translocation identified a fusion transcript that was created as a result of combining the newly identified genes: MECT1 (mucoepidermoid carcinoma translocated gene-1) from the $19 \mathrm{p} 13$ region and MAML2 (mastermind-like gene family 2) from the $11 q 21$ region. It was found that a new protein activates the Notch pathway genes, encoding signalling proteins responsible for the control of cell differentiation [49, 50].

Research on the H-Ras oncogene showed $18 \%$ of mutations in codon 12. It is probably one of the causes of tumourigenesis and progression of these cancers. These mutations were mainly present in the tumours with a high differentiation rate [51].

Except for the above, an occasional loss of genetic material (demonstrated within areas 9p21, 8q, 5p, 12p, and $16 q)$ was reported. However, this requires further molecular analysis [52].

\section{Molecular features of prognostic and 9}

The members of EGFR (epidermal growth factor receptor) pathway have shown a high expression level, and according to several studies they can be a potential target in the therapy of MEC [53].

Actin regulatory protein - Mena, which is involved in cell motility and adhesion, was positive in high-grade mucoepidermoid carcinomas and negative in low-grade mucoepidermoid carcinomas. In other studies, it was observed that Mena was up-regulated and it facilitated metastasis in breast, pancreatic, and colorectal carcinomas and melanomas. Apparently, this protein might help pathologists in the correct staging and proper predicting of prognosis for MEC $[14,15]$.

\section{Adenoid cystic carcinoma \\ Cytogenetic and molecular aspects}

Despite numerous studies in the field of cytogenetics and molecular biology of ACC, the reported results are often unclear or even contradictory. The most consistent information confirms the chromosomal aberrations in the $6 q, 9 p$, and 17p12-13 regions, which mostly results in deletions. It also appears that the translocation $\mathrm{t}(6,9)$ (q21-24,p13-23) is specific for this tumour and is treated as a primary change for further mutations. This results in a fusion of genes of transcription factors MYB and NFIB, and is associated with a poorer prognosis [54-56]. The deletion of 1p32-p36 fragment is a factor that is also associated with decreased survival rates [57].

A recent study of 25 cases of ACC showed a high frequency of the loss of heterozygosity in the 6q23-25, which positively correlated with the low degree of differentiation and aggressive clinical behaviour of ACC $[58,59]$. Moreover, the same authors described the hypermethylation of the gene promoter - p16, which is specific for this tumour. Therefore, there are great hopes of determining a marker in the practical aspect [60]. The hypomethylation and overexpression of $A Q P 1$ (aquaporin-1) was also proven to be characteristic for ACC tumours. It was also observed that muted $A Q P 1$ inhibited the proliferation of tumour cells 
in an animal model, which seems to be a promising therapeutic target [61].

The profile of ACC gene expression, using microarrays containing 8920 human genes, has shown an abnormal expression of genes encoding transcription factors, such as AP-SOX4, 2a, and genes engaged in one of the signalling pathways - Wnt/ $\beta$-catenin. A similar picture characterises the carcinogenesis of other common tumours such as breast or lung cancer and melanoma $[62,63]$.

\section{Prognostic and predictive values of the molecular features}

Eighty to ninety percent of ACC tumours demonstrate overexpression of c-Kit (also known as CD117), while 20\% show overexpression of EGFR (epidermal growth factor receptor). There is ongoing research concerning anti-EGFR therapy with drugs such as lapatinib, erlotinib, and cetuximab, but it is still at an early stage [64-66]. Increased expression of cytokines has also been described for Cox-2, IL-6, and IL-8, which may be considered as potential targets for chemotherapeutic agents [66]. Many reports have confirmed changes in expression, loss of heterozygosity, and microsatellite instability connected with the tumour suppressor genes - p53 and $R b$. However, the importance of this fact also requires further clarification [67].

There are some new data showing that under hypoxic conditions hypoxia-inducible factor-1 (HIF-1) $\alpha$-dependent VEGF overexpression shows some associations with the metastatic tendency of ACC cells, and may function as a potential target for ACC therapy [68].

\section{Carcinoma ex pleomorphic adenoma}

The histopathological, biological, and genetic features of CA ex PA lesions appear to be closely correlated. Previous reports in the field of cytogenetics informed about deletions in chromosome 5 regions (q22-23, q32-33) and translocations $t(10 ; 12)(p 15 ; q 14-15)$ when the segment containing the HMGIC and MDM2 genes (known as oncogenes in other malignancies) is transmitted, resulting in the amplification and overexpression of these genes [69-71]. Alterations in the long arms of chromosomes 8 and 12 were also described. However, while the loss of heterozygosity $(\mathrm{LOH})$ within them is associated primarily with the development of benign PA, the emergence of additional changes within the short arm of chromosome 17 is associated with its malignant transformation to CA ex PA. Moreover, changes in chromosome 17 are significantly correlated with a high proliferative index and the severity of the disease [52, 72, 73]. However, what still seems to be controversial is the abnormal expression of the Tp53 gene, which is located within the 17p13. The deletions were described in this particular area. However, it does not fully translate into the level of expression of this protein in immunohistochemical studies [12, 13]. It was also suggested that the inactivation of p21 may play an important role in the development of CA ex PA, and this protein behaves as dependent or independent of p53 [74].
CA ex PA, especially the component originating from ducts, shows an increased expression of the oncogene c-erbB-2-membrane receptor, demonstrating homology to the EGFR, which, according to one study, could be used as a marker determining malignant transformation [75, 76]. According to Suzuki, the deletion of p16 gene located within the 9p21, known as a tumour suppressor gene, plays a role in the carcinogenesis of CA ex PA [77]. Some authors described the great importance of this alteration in the development of e.g. melanoma [12, 77, 78]. It was also suggested that there is an inverse correlation of $p 16$ and $p R b$ expression. Therefore, if $p 16$ or $p R b$ is inactivated the other gene will show an overexpression [79].

With reference to earlier reports, we have failed to provide the results of wider research on microsatellite instability (MSI), which is mainly observed in hereditary cancers $[73,77]$.

\section{Prognostic and predictive values of the molecular features}

There are new data confirming that the downregulation of the Wnt inhibitory factor 1 (WIF1) is widespread in salivary gland CA ex PA, and that WIF1 downregulation also occurs in the CA ex PA precursor lesions - PA, which indicates a higher risk of progression from benign to malignant lesions [80].

The continuous development of molecular techniques enables constant broadening the knowledge of the genesis and biology of tumours originating from the tissues of salivary glands. Unfortunately, this process is slower in comparison with more common malignancies, such as breast, lung, or colon cancer. It is mainly due to the longer period that is necessary to collect tissue material for testing, especially as regards those relatively rare malignancies.

In recent years, many molecular studies have elucidated the multistage model of the carcinogenesis of these tumours. However, further investigations need to be undertaken to incorporate the concept of personalised medicine, or individually targeted treatment of salivary gland tumours, based on each patient's unique clinical, genetic, and environmental characteristics. The possibility of early diagnosis, considering the patient's predisposition to recurrence or malignant evolution of benign salivary gland tumours, facilitate the expansion of the first-line treatment. Therefore, the patient may be protected from further interventions related to oncological treatment.

The authors declare no conflict of interest.

\section{References}

1. Barnes L, Eveson JW, Reichart P, Sidransky D. Pathology and genetics of head and neck tumors. World Health Organization Classification of tumors. IARC, Lyon 2005.

2. Kopeć T, Wierzbicka M, Szyfter W, Bem G. Incidence of salivary gland malignancies in 12 year time period in the ENT Department of Medical University in Poznan. Polish Otolaryngology 2010; 64: 288-95. 
3. Bień S, Ziółkowska M, Kamiński B, Klimas A, Okła S, Postuła S, Żyłka S. Clinical and epidemiological assessment of salivary gland tumors. Medical Studies of Swietorzyska Academy 2006; 3: 21-30.

4. Rahnama M, Orzędała-Koszel U, Czupkałło Ł, Łobacz M. Pleomorphic adenoma of the palate: a case report and review of the literature. Contemp Oncol 2013; 17: 103-6.

5. Didkowska J, Zatoński W. The National Cancer Registry, Raport 2011.

6. Edge SB, Byrd DR, Compton CC, Fritz, AG, Greene FL, Trotti A. Ma jor salivary glands (parotid, submandibular, and sublingual). AJCC Cancer Staging Manual. $7^{\text {th }}$ ed. New York 2010; 9-82.

7. Wierzbicka M, Kopeć T, Szyfter W, Bem G. Epidemiology of non-malignant salivary gland tumors based on 675 cases, Polish Otolaryngology 2010; 64: 281-7.

8. Eveson JW, Auclair P, Gnepp DR, El-Naggar AK. Tumours of the salivary glands: introduction. In: Barnes L, Eveson JW. World Health Organization Classification of Tumours. IARC, Lyon 2005; 212-25.

9. Edwards PC, Bhuiya T, Kelsch RD. C-kit expression in the salivary gland neoplasms adenoid cystic carcinoma, polymorphous lowgrade adenocarcinoma, and monomorphic adenoma. Oral Surg Oral Med Oral Pathol Oral Radiol Endod 2003; 95: 586-93.

10. Skalova A, Starek I, Vanecek T, Kucerová V, Plank L, Szépe P, Di Palma S, Leivo I. Expression of HER-2/neu gene and protein in salivary duct carcinomas of parotid gland as revealed by fluorescence in-situ hybridization and immunohistochemistry. Histopathology 2003; 42: 348-56

11. Bell D, Ehab YH. Salivary gland cancers: biology and molecular targets for therapy. Curr Oncol Rep 2012; 14: 166-74.

12. Alves FA, Pires FR, De Almeida OP, Lopes MA, Kowalski LP. PCNA, Ki67 and 553 expressions in submandibular salivary gland tumours. Int J Oral Maxillofac Surg 2004; 33: 593-7.

13. Kärjä VJ, Syrjänen KJ, Kurvinen AK, Syrjänen SM. Expression and mutations of p53 in salivary gland tumours. J Oral Pathol Med. 1997; 26: 217-23.

14. Gurzu S, Krause M, Ember I, Azamfirei L, Gobel G, Feher K, Jung I. Mena, a new available marker in tumors of salivary glands? Eur J Histochem 2012; 56: e8.

15. Gurzu S, Ciortea D, Ember I, Jung I. The possible role of Mena pro tein and its splicing-derived variants in embryogenesis, carcino genesis, and tumor invasion: a systematic review of the literature. Biomed Res Int 2013; 2013: 365192.

16. Leader R, Deol-Poonia RK, Sheard J, Triantafyllou A. Immunohistochemical localization of WT1 in epithelial salivary tumors. Pathol Res Pract 2014; 210: 726-32.

17. Ohtomo R, Mori T, Shibata S, Tsuta K, et al. SOX10 is a novel marker of acinus and intercalated duct differentiation in salivary gland tumors: A clue to the histogenesis for tumor diagnosis. Mod Pathol 2013; 26: 1041-50.

18. Yanai H, Sato Y, Nagatsuka H, Yoshino T. Nestin is a wide-spectrum abluminal cell marker of salivary gland tumors. Pathol Int 2013; 63: 496-501.

19. Vered M, Allon I, Tunis TS, Buchner A, Dayan D. Expression of the homeostasis-related markers, maspin, heat shock proteins 70 \& 90, glutathione S-transferase, aquaporin 5 and NF-kB in young and old labial and palatal salivary glands. Exp Gerontol 2013; 48: 444-50.

20. Senft E, Lemound J, Stucki-Koch A, Gellrich NC, Kreipe H, Hussein K. Expression of cyclin-dependent kinase inhibitor 2A 16, tumour protein 53 and epidermal growth factor receptor in salivary gland carcinomas is not associated with oncogenic virus infection. Int J Oral Sci 2014; 11.

21. Mark J, Dahlenfors R, Wedell B, Impact of the in vitro technique used on the cytogenetic patterns in pleomorphic adenomas, Cancer Genet Cytogenet 1997; 95: 9-15.

22. Bullerdiek J, Wobst G, Meyer-Bolte K, Chilla R, Haubrich, J, Thode B, Bartnitzke S, Cytogenetic subtyping of 220 salivary gland pleomorphic adenomas: correlation to occurrence, histological subtype, and in vitro cellular behavior, Cancer Genet Cytogenet 1993; 65: 27-31.

23. Martins C, Fonseca I, Roque L, Pereira T, Ribeiro C, Bullerdiek J, Soares J. PLAG1 gene alterations in salivary gland pleomorphic adenoma and carcinoma ex-pleomorphic adenoma: a combined study using chromosome banding, in situ hybridization and immunocytochemistry. Mod Pathol 2005; 18: 1048-55.

24. Astrom A, Voz M, Kas K, Roijer E, Wedell B, Mandahl N, Van de Ven W, Conserved mechanism of PLAG1 activation in salivary gland tumours with and without chromosome $8 \mathrm{q} 12$ abnormalities: identification of SII as a new fusion partner gene. Cancer Res 1999; 59: 918-23.

25. Martins C, Fonseca I, Félix A, Roque L, Soares J, Benign salivary gland tumours: a cytogenetic study of 21 cases. J Surg Oncol 1995; 60: 232-7.

26. Mark J, Dahlenfors R, Wedell B, Impact of the in vitro technique used on the cytogenetic patterns in pleomorphic adenomas. Cancer Genet Cytogenet 1997; 95: 9-15.

27. Tsang YT, Chang YM, Lu X, Rao PH, Lau CC, Wong KK. Amplification of MGC2177, PLAG1, PSMC6P, and LYN in a malignant mixed tumour of salivary gland detected by CDNA microarray with tyramide signal amplification. Cancer Genet Cytogenet 2004; 152: 124-8.

28. Milasin J, Pujic N, Dedovic N, Gavric M, Vranic V, Petrovic V, Minic A. $\mathrm{H}$-ras gene mutations in salivary gland pleomorphic adenomas. Int J Oral Maxillofac Surg 1993; 22: 359-61.

29. Rosa JC, Felix A, Fonseca I, Soares J. Immunoexpression of c-erbB-2 and p53 in benign and malignant salivary neoplasms with myoepithelial differentiation. J Clin Pathol 1997; 50: 661-3.

30. Webb S. MicroRNA reins in tumour-initiating cells. Nature Reports Stem Cells 2008; doi: 10.1038/stemcells.2007.137.

31. Webb AJ, Eveson JW. Pleomorphic adenomas of the major salivary glands: a study of the capsular form in relation to surgical management. Clin Otolaryngol 2001; 26: 134-42.

32. Geurts JM, Schoenmakers EF, Roijer E, Astrom AK, Stenman G, Van de Ven WJ. Identification of NFIB as recurrent translocation partner gene of HMGIC in pleomorphic adenomas. Oncogene 1998; 16: 865-72.

33. Geurts JM, Schoenmakers EF, Roijer E, Stenman G, Van de Ven WJ. Expression of reciprocal hybrid transcripts of HMGIC and FHIT in a pleomorphic adenoma of the parotid gland. Cancer Res 1997; 57: 13-7.

34. Voz ML, Astrom AK, Kas K, Mark J, Stenman G, Van de Ven WJ. The recurrent translocation $\mathrm{t}(5 ; 8)(\mathrm{p} 13 ; \mathrm{q} 12)$ in pleomorphic adenomas results in upregulation of PLAG1 gene expression under control of the LIFR promoter. Oncogene 1998; 16: 1409-16.

35. Wemmert S, Willnecker V, Brunner C, Wenzel GI, Sauter B, Meinelt H, Bartholmé N, Saada C. New genetic findings in parotid gland pleomorphic adenomas. Head Neck 2013; 35: 1431-8.

36. Weber A, Langhanki L, Schütz A,Gerstner A, Bootz F, Wittekind C, Tannapfel A. Expression profiles of p53, p63, and p73 in benign salivary gland tumours. Virchows Arch 2002; 441: 428-36.

37. Pantelis A, Wenghoefer M, Haas S, Merkelbach-Bruse S, Pantelis D, Jepsen S, Bootz F, Winter J. Down regulation and nuclear localization of human beta-defensin-1 in pleomorphic adenomas of salivary glands. Oral Oncol 2009; 45: 526-30.

38. Martinelli M, Martini F, Rinaldi E, et al. Simian virus 40 sequences and expression of the viral large $T$ antigen oncoprotein in human pleomorphic adenomas of parotid glands. Am J Pathol 2002; 161: 1127-33.

39. Pastore A, Carinci F, Pelucchi S. Genetic expression profiling of parotid neoplasms by cDNA microarrays. Acta Otorhinolaryngol Ital 2005; 25: 153-60.

40. Song M, Xiao C, Wang T, Pei Q, Wang S, Xu L, Chen W. Study of the differentially expressed genes in pleomorphic adenoma using cDNA microarrays. Pathol Oncol Res 2011; 17: 765-9.

41. Zhang X, Cairns M, Rose B, O’Brien C, Shannon K, Clark J, Gamble J, Tran N. Alterations in miRNA processing and expression in pleomorphic adenomas of the salivary gland. Int J Cancer 2009; 124: 2855-63.

42. Nordkvist A, Mark J, Dahlenfors R, Bende M, Stenman G. Cytogenetic observations in 13 cystadenolymphomas (Warthin's tumours). Cancer Genet Cytogenet 1994; 76: 129-35.

43. Mark J, Dahlenfors R, Stenman G, Nordquist A. A human adenolymphoma showing the chromosomal aberrations del (7)(p12p1415) and t(11;19) (q21;p12-13). Anticancer Res 1989; 9: 1565-6. 
44. Lewis PD, Baxter P, Paul Griffiths A, Parry JM, Skibinski DO. Detec tion of damage to the mitochondrial genome in the oncocytic cells of Warthin's tumour. J Pathol 2000; 191: 274-81.

45. Honda K, Kashima K, Daa T, Yokoyama S, Nakayama I. Clonal analysis of the epithelial component of Warthin's tumour. Hum Pathol 2000; 31: 1377-80.

46. Rosai J, Suster S. Warthin's tumours. Hum Pathol 2001; 32: 352.

47. El Naggar AK, Lovell M, Killary AM, Clayman GL, Batsakis JG. A mucoepidermoid carcinoma of minor salivary gland with $t(11 ; 19)$ (q21;p13.1) as the only karyotypic abnormality. Cancer Genet Cytogenet 1996; 87: 29-33.

48. Horsman DE, Berean K, Durham JS. Translocation (11;19)(q21;p13.1) in mucoepidermoid carcinoma of salivary gland. Cancer Genet Cytogenet 1995; 80: 165-6.

49. Enlund F, Behboudi A, Andrén Y, Oberg C, Lendahl U, Mark J, Stenman G. Altered Notch signaling resulting from expression of a WAMTP1-MAML2 gene fusion in mucoepidermoid carcinomas and benign Warthin's tumours. Exp Cell Res 2004; 292: 21-8.

50. Martins C, Cavaco B, Tonon G, Kaye FJ, Soares J, Fonseca I. A study of MECT1-MAML2 in mucoepidermoid carcinoma and Warthin's tumour of salivary glands. J Mol Diagn 2004; 6: 205-10.

51. Yoo J, Robinson RA. Ras gene mutations in salivary gland tumours Arch Pathol Lab Med 2000; 124: 836-9.

52. Johns MM 3rd, Westra WH, Califano JA, Eisele D, Koch WM, Sidransky D. Allelotype of salivary gland tumours. Cancer Res 1996; 56: 1151-4.

53. Gibbons MD, Manne U, Carroll WR, Peters GE, Weiss HL, Grizzle WE. Molecular differences in mucoepidermoid carcinoma and adenoid cystic carcinoma of the major salivary glands. Laryngoscope 2001; 111: 1373-8.

54. Jin C, Martins C, Jin Y, et al. Characterization of chromosome ab errations in salivary gland tumours by FISH, including multicolor COBRA-FISH. Genes Chromosomes Cancer 2001; 30: 161-7.

55. Nordkvist A, Mark J, Gustafsson H, Bang G, Stenman G. Non-random chromosome rearrangements in adenoid cystic carcinoma of the salivary glands. Genes Chromosomes Cancer 1994; 10: 115-21.

56. Sandros J, Mark J, Happonen RP, Stenman G. Specificity of 6qmarkers and other recurrent deviations in human malignant salivary gland tumours. Anticancer Res 1988; 8: 637-43.

57. Rao PH, Roberts D, Zhao YJ, Bell D, Harris CP, Weber RS, El-Naggar AK. Deletion of 1p32-p36 is the most frequent genetic change. and poor prognostic marker in adenoid cystic carcinoma of the salivary glands. Clin Cancer Res 2008; 14: 5181-7.

58. Queimado L, Reis A, Fonseca I, Martins C, Lovett M, Soares J, Parreira $L$. A refined localization of two deleted regions in chromosome $6 \mathrm{q}$ associated with salivary gland carcinomas. Oncogene 1998; 16: 83-8.

59. Stallmach I, Zenklusen P, Komminoth P, et al. Loss of heterozygos ity at chromosome 6q23-25 correlates with clinical and histologic parameters in salivary gland adenoid cystic carcinoma. Virchows Arch 2002; 440: 77-84.

60. Maruya S, Kurotaki H, Shimoyama N, Kaimori M, Shinkawa H, Yagihashi S. Expression of p16 protein and hypermethylation status of its promoter gene in adenoid cystic carcinoma of the head and neck. ORL J Otorhinolaryngol Relat Spec 2003; 65: 26-32.

61. Shao C, Sun W, Tan M, et al. Integrated, genome-wide sreening for hypomethylated oncogenes in salivary gland adenoid cystic carcinoma. Clin Cancer Res 2011; 17: 4320-30.

62. Frierson HFJr, El Naggar AK, Welsh JB, et al. Large scale molecular analysis identifies genes with altered expression in salivary adenoid cystic carcinoma. Am J Pathol 2002; 161: 1315-23.

63. Lamparska-Przybysz M, Wieczorek M, Majorek M, Guzenda P. The role of the $W n t / \beta$-catenin in the molecular mechanism of tumour processes, Contemp Oncol (Pozn) 2006; 10: 497-501.

64. Agulnik M, Cohen EW, Cohen RB, Chen EX, Vokes EE, Hotte SJ. Phase II study of lapatinib in recurrent or metastatic epidermal growth factor receptor and/or erbB2 expressing adenoid cystic carcinoma and non adenoid cystic carcinoma malignant tumours of thesalivary glands. J Clin Oncol. 2007; 25: 3978-84.

65. Bell D, Roberts D, Kies M, Rao P, Weber RS, El-Naggar AK. Cell type-dependent biomarker expression in adenoid cystic carcinoma: biologic and therapeutic implications. Cancer 2010; 116: 5749-56.
66. Zhang J, Peng B, Chen X. Expressions of nuclear factor B, inducible nitric oxide synthase, and vascular endothelial growth factor in adenoid cystic carcinoma of salivary glands: correlations with the angiogenesis and clinical outcome. Clin Cancer Res 2005; 11: 7334.

67. Yamamoto Y, Virmani AK, Wistuba II, Mclntire D, Vuitch F, Albores-Saavedra J, Gazdar AF. Loss of heterozygosity and microsatellite alterations in p53 and RB genes in adenoid cystic carcinoma of the salivary glands. Hum Pathol 1996; 27: 1204-10.

68. Kondo S, Mukudai Y, Soga D, Nishida T, Takigawa M, Shirota T. Differential expression of vascular endothelial growth factor in high- and low-metastasis cell lines of salivary gland adenoid cystic carcinoma. Anticancer Res 2014; 34: 671-7.

69. El Naggar AK, Lovell M, Callender DL, Ordonez NG, Killary AM. Concurrent cytogenetic, interphase fluorescence in situ hybridization and DNA flow cytometric analyses of a carcinoma ex-pleomorphic adenoma of parotid gland. Cancer Genet Cytogenet 1998; 107: 132-6.

70. Jin C, Martins C, Jin Y, Wiegant J, Wennerberg J, Dictor M, Gisselsson D, Strombeck B, et al. Characterization of chromosome aberrations in salivary gland tumours by FISH, including multicolor COBRA-FISH. Genes Chromosomes Cancer 2001; 30: 161-7.

71. Rao PH, Murty VV, Louie DC, Chaganti RS. Nonsyntenic amplification of MYC with CDK4 and MDM2 in a malignant mixed tumour of salivary gland. Cancer Genet Cytogenet 1998; 105: 160-3.

72. El-Naggar AK, Dinh M, Tucker SL, Gillenwater A, Luna MA, Batsakis JG. Chromosomal and DNA ploidy characterization of salivary gland neoplasms by combined FISH and flow cytometry. Hum Pathol 1997; 28: 881-6.

73. El Naggar AK, Callender D, Coombes MM, Hurr K, Luna MA, Batsakis JG. Molecular genetic alterations in carcinoma ex-pleomorphic adenoma: a putative progression model? Genes Chromosomes Cancer 2000; 27: 162-8.

74. Tarakji B, Baroudi K, Hanouneh S, Nassani MZ, Alotaibi AM, Kharma MY, Azzeghaiby SN. Expression of p21 is dependent on or independent of p53 in carcinoma ex pleomorphic adenoma (undifferentiated and adenocarcinoma types). Pol J Pathol 2012; 63: 286-91.

75. Freitas LL, Araújo VC, Martins MT, Chone C, Crespo A, Altemani A. Biomarker analysis in carcinoma ex pleomorphic adenoma at an early phase of carcinomatous transformation. Int I Surg Pathol 2005; 13: 337-42

76. Di Palma S, Skálová A, Vanìeek T, Simpson RH, Stárek I, Leivo I. Non-invasive (intracapsular) carcinoma ex pleomorphic adenoma: recognition of focal carcinoma by HER-2/neu and MIB1 immunohistochemistry. Histopathology 2005; 46: 144-52

77. Suzuki H, Fujioka Y. Deletion of the p16 gene and microsatellite instability in carcinoma arising in pleomorphic adenoma of the parotid gland. Diagn Mol Pathol 1998; 7: 224-31.

78. Ohki K, Kumamoto H, Ichinohasama R, Suzuki M, Yamaguchi T, Echigo S, Motegi K, Ooya K. Genetic analysis of DNA microsatellite loci in salivary gland tumours: comparison with immunohistochemical detection of hMSH2 and p53 proteins. Int J Oral Maxillofac Surg 2001; 30: 538-44.

79. Tarakji B, Alenzi F, Al-khuraif AA. Assessment of inverse correlation of p16 and pRb expression in carcinoma ex pleomorphic adenoma. Pol J Pathol 2013; 2: 144-8.

80. Ramachandran I, Ganapathy V, Gillies E, Fonseca I, Sureban SM, Houchen CW, Reis A, Queimado L. Wnt inhibitory factor 1 suppresses cancer stemness and induces cellular senescence. Cell Death Dis 2014; 22: e1246.

\section{Address for correspondence}

\section{Aleksandra J. Ochal-Choińska}

Department and Chair of Otolaryngology

Medical University of Warsaw

Banacha $1 \mathrm{~A}$

02-097 Warsaw, Poland

e-mail: aleksandra.ochal@gmail.com

Submitted: 31.10 .2013

Accepted: 24.04 .2015 